\title{
АРТ-ТЕРАПЕВТИЧНІ ТЕХНОЛОГІЇ В ОСВІТНІЙ СОЦІАЛІЗАЦЇ̈ ДІТЕЙ З ІНТЕЛЕКТУАЛЬНИМИ ПОРУШЕННЯМИ
}

Хіля А. В., Саранча I. Г.

\section{ВСТУП}

Питання організації навчання дітей з порушеннями інтелекту досить широко представлено різноманітним спектром досліджень, наукових праць i практичних пошуків, основна частина яких базується на матеріалах олігофренопедагогіки, спеціальної та корекційної педагогіки. Але на зміну вже відомій моделі медичної соціалізації дітей 3 інвалідністю й сегрегованому навчанню прийшла інклюзивна освітня модель, що поставило низку питань теоретико-методологічного та практичного характеру до освітянської спільноти.

Так, за останне десятиліття питання роботи 3 дітьми цієї категорії досліджували науковці, а саме: І. Татьянчикова «Психолого-педагогічні основи соціалізації дітей 3 вадами інтелектуального розвитку» (2015 р.), Н. Бабич «Формування комунікативних навичок у старших дошкільників 3 порушеннями зору та інтелекту» (2016 р.), О. Хайдарова «Формування уявлень про навколишній світ у молодших школярів 3 інтелектуальними порушеннями» (2018р.), С. Березка «Особливості психокорекції поведінкових розладів дітей з порушенням інтелектуального розвитку засобами арт-терапії» (2019р.). Але основна частина цих досліджень спрямована на фахівців, які мають спеціальну освіту, тоді як, відповідно до нових вимог і законодавства України, вихователь, учитель та асистент закладу дошкільної освіти чи загальноосвітнього навчального закладу для організації інклюзивної групи чи класу не потребують спеціальної корекційної освіти. 3 одного боку, це ускладнює процеси адаптації як дитини до освітнього середовища, так і педагогічного колективу до нових вимог та умов забезпечення якості освітнього процесу.

Але, на відміну від педагогічних працівників, що мають спеціальну освіту та працюють відповідно до компетенції та критеріїв, визначених для закладів спеціальної освіти, в інклюзивній освіті педагогу необхідно максимальну увагу зосередити на питаннях соціалізації дитини з інвалідністю. саме тому, на нашу думку, варто особливу увагу в освітній соціалізації дітей з інтелектуальними порушеннями звернути на арт-терапевтичні технології. 


\section{1. Особливості соціалізації дитини з інтелектуальними порушеннями в умовах інклюзивного навчання}

\section{1. Підходи й моделі розподілу організації освіти для різних груп дітей з інтелектуальними порушеннями}

Для якісної організації інклюзивних процесів у закладі дошкільної освіти чи загальноосвітньому навчальному закладі педагогічні працівники мають розуміти специфіку розвитку дітей з інвалідністю, зокрема дітей з інтелектуальними порушеннями. Саме тому, на нашу думку, як одну 3 основних варто розглядати медичну модель інвалідності й відповідні групи розумово відсталих за ступенем інтелектуального порушення.

Так, відповідно до визначених Всесвітньою організацією охорони здоров’я в перегляді Міжнародної класифікації хвороб, О. Гаврилов пропонує ознайомитися з такими групами розумової відсталості:

- легка розумова відсталість;

- помірна розумова відсталість;

- тяжка розумова відсталість;

- глибока розумова відсталість;

- інша розумова відсталість;

- неуточнена розумова відсталість.

Окрім того, як зазначає автор, коло патологій, що можуть призвести до відповідного діагнозу, досить широке, а саме:

- дисгенетичні й диспластичні захворювання мозку (аненцефалія; вроджений недорозвиток центральної нервової системи; мікроцефалія);

- хромосомні захворювання людини (синдром Дауна, синдром Кляйнфельтера; синдром Тернера; синдром трисомії-X; синдром Штурге-Вебера-Краббе; делеції; транслокації);

- сімейні форми олігофренії (акроцефалосиндактилія (синдром Аперта); синдром Крузона; синдром Сьоргена-Ларссона; синдром Б'єрсона-Форсмана-Леємана; міотонічна дистрофія; синдром ПрадераВіллі);

- непрогредієнтні стани екзогенної етіології, які супроводжуються синдромом олігофренії (пологова травма із синдромом олігофренічної розумової відсталості; гідроцефалія; поренцефалія; вроджений токсоплазмоз; краснуха вагітних; вроджений сифіліс; вітамінна недостатність i дистрофія в дітей; гемолітична хвороба новонароджених);

- синдром олігофренії ендокринного генезу (недостатність щитовидної залози; недостатність гіпофізарних функцій; ахондроплазія; хвороба Іценко-Кушінга; нецукровий діабет і хвороба Фреліха; цукровий діабет; статеві аномалії); 
- прогредієнтні процеси, які призводять до втрати інтелектуального потенціалу, пов'язані 3 дисферментозом (синдром Гулера, хвороба Ганда-Шюлера-Христіана; хвороба Леттера-Зіве; хвороба Німана-Піка (генералізований сфінгомієліноз); хвороба Гоше (керазіновий ретикулоендотеліоз); галактоземія; глікогенна хвороба; фенілпіровиноградна олігофренія; амавротична ідіотія Тей-Сакса; хвороба Вільсона; синдром Лоуренса-Муна-Бідля-Барде; хвороба Паліцеуса-Мерцбахера; міоклонус-епілепсія (міоклонія) Унферріхта);

- захворювання, які супроводжуються розвитком і зміною функцій певних тканин (остеопетроз (синдром Альберса-Шенберга); туберозний склероз (епілойя, хвороба Бурневілля); нейрофіброматоз (хвороба Реклінгаузена); вертикальна складчастість шкіри; олігофренія 3 ектодермальною дисплазією; краніостеноз; щелепно-лицьовий дизостоз; олігофренії з кістковими аномаліями й пороками розвитку кісткової системи; синдром Марфана; прогресуючий костевніючий міозит) ${ }^{1}$.

Навіть якщо просто переглянути означений перелік, стає зрозуміло, що «похапцем» отримані знання щодо організації роботи 3 дітьми 3 інтелектуальними порушеннями та якісного супроводження процесу соціалізації таких дітей в інклюзивному освітньому середовищі можуть мати досить неоднозначні результати, оскільки досить часто в «побуті» ми можемо згадати лише те, що $\epsilon$ розумова відсталість і синдром Дауна, тоді як кожна 3 патологій розвитку інтелектуальної сфери може мати суттєві відмінності й «неочікуваний» для непідготовленого педагогічного працівника прояв у розвитку дитини.

Окрім того, на нашу думку, варто згадати класифікацію, якою частіше користуються в педагогіці, зокрема в олігофренопедагогіці. У цьому разі ми маємо такі види порушень: дебільність, імбецильність, ідіотія, а також сьогодні класифікація включає затримку психічного розвитку та педагогічно занедбаних дітей ${ }^{2}$. Варто відзначити, що навіть невеликий перелік педагогічної моделі класифікації не зменшує обсягу інформації та різноманітності в межах представленої інвалідності. Крім того, як зазначає О. Гаврилов, в Україні не готують спеціалістів, які б працювали $з$ такою категорією дітей, адже корекційна, реабілітаційна, навчальна, виховна робота 3 ними має свою специфіку ${ }^{3}$. Спеціальна

${ }^{1}$ Гаврилов О.В. Особливі діти в закладі і соціальному середовищі : навчальний посібник. Кам'янець-Подільський : Аксіома, 2009. 308 с.

2 Березка С.Ф. Особливості психокорекції поведінкових розладів дітей 3 порушенням інтелектуального розвитку засобами арт-терапії : автореф. дис. ... канд. психол. наук : 19.00.08. Київ, 2019. 21 с.

${ }^{3}$ Гаврилов О.В. Особливі діти в закладі і соціальному середовищі : навчальний посібник. Кам'янець-Подільський : Аксіома, 2009. 308 с. 
підготовка олігофренопедагогів також не забезпечує грунтовних знань 3 проблеми організації роботи із цієї групою дітей різного віку через низку причин, із чим ми, безсумнівно, погоджуємося.

Також уважаємо, що варто згадати, що сьогодні асистент учителя, вихователя, відповідно до кваліфікаційної рамки професії, може не мати спеціальної освіти. Це також не сприяє соціалізації дитини з будь-якою інвалідністю, оскільки вихователі й учителі інклюзивної групи чи класу не мають спеціальної освіти. Уведення в штат учителя-логопеда, учителяреабілітолога чи дефектолога сприяє формуванню мультидисциплінарної команди, яка має спільно забезпечувати пошуки найкращих шляхів організації життя дитини з інвалідністю в групі чи класі.

Погоджуючись із твердженням С. Берези щодо підходів, які варто використовувати в спеціальній педагогіці, ми також розглядаємо психологічний підхід як дієвий для педагогіки інклюзивної освіти, оскільки саме цей підхід дає змогу врахувати всі причини та чинники розвитку поведінкових розладів (у тому числі й психологічного характеру) у дітей з порушенням інтелектуального розвитку, а також підхід дає можливість комплексно дослідити проблему, здійснювати психокорекцію поведінки дитини в рамках закладів освіти ${ }^{4}$.

Отже, відбувається поступовий перехід від спеціальної освіти й соціального обмеження дітей з інвалідністю до інклюзивної освітньої моделі та зміцнення соціальних зав'язків.

\section{2. Індивідуальний підхід до питань організації освіти дітей з інтелектуальними порушеннями}

У процесі опрацювання сучасних підходів до організації інклюзивної освіти досить часто педагоги звертаються до іноземного досвіду. Зокрема, перша модель інклюзивної освіти базувалася на канадському досвіді та впроваджувалася з 2010 по 2014 роки. Виявлено низку переваг такої форми навчання, але були причини для подальшої адаптації та модифікації цієї моделі.

Так, до переваг варто зарахувати:

- суттєві теоретичні й методичні напрацювання в цьому напрямі, які й сьогодні залишаються в основі підготовки асистентів;

- якісно розроблений адміністративний апарат, що має забезпечити дієвий алгоритм уведення інклюзивної моделі в заклади освіти й відповідне документальне супроводження цього процесу;

- коректно сформований алгоритм взаємодії мультидисциплінарної команди для забезпечення психолого-педагогічного супроводу дитини;

- тощо.

4 Березка С.Ф. Особливості психокорекції поведінкових розладів дітей 3 порушенням інтелектуального розвитку засобами арт-терапії : автореф. дис. ... канд. психол. наук : 19.00.08. Київ, 2019. 21 с. 
Водночас до таких, що не виправдовують перенесення моделі інших країн без відповідної адаптації чи модифікації на українські реалії в освітній галузі, можна зарахувати введення та використання форми роботи 3 дітьми 3 інвалідністю за кордоном, зокрема й дітьми 3 розумовою відсталістю. Як зазначає О. Гаврилов, часто технології, що пропонуються західними авторами, використовуються спеціалістами України без цієї апробації та можуть призвести до викривлення вже порушеного розвитку, травмувати дитину й зумовити зменшення розвитку компенсаторних механізмів, що, у свою чергу, знизить якість корекційних і реабілітаційних впливів. Окрім того, це впливатиме й на професійне становлення спеціалістів, формуючи в них негативне ставлення до всього нового, створюючи інертний простір навколо системи організації роботи 3 інтелектуальними порушеннями в різновікових групах 5 .

Але варто відзначити й особливості закордонної практики наукового висвітлення результатів роботи 3 дітьми 3 інвалідністю. Зокрема, у більшості випадків дослідники цієї тематики з Свропи чи США розкривають використання певних технологій на окремому прикладі. Так, беручи за основу роботу з декількома дітьми зі схожими патологіями розвитку дітей, науковці, дослідники та практики покроково описують роботу саме із цією дитиною, ураховуючи іiі особливості розвитку, тип темпераменту, прагнення та бажання, у тому числі методи та форми роботи, які є дієвими й ефективними в цьому конкретному випадку. Зокрема, 3 такою схемою опису можна ознайомитися в педагогічній праці O. Ivar Lovaas ${ }^{6}$, тоді як науковці України зазвичай описують загальну характеристику певної категорії дітей 3 інвалідністю, зокрема й інтелектуальними порушеннями, звертаючись до узагальненого досвіду використання тієї чи іншої технології в умовах спеціальної школи чи закладів соціальнопсихологічної реабілітації.

Окрім того, у сучасному доробку варто відзначити такі книжки художньої літератури, які можуть сприяти розумінню особливостей дітей з інвалідністю: «Out of my mind» by Sharon M. Draper (2010), «We're amazing 1,2,3! A story about friendship and autism (Big golden book)» by Leslie Kimmelman and Beth Nelson (2017) тощо. В Україні цей напрям також розвивається й представлений авторським доробком К. Бабкіної, А. Бачинського, О. Бутковської, К. Сгорушкіної,

${ }^{5}$ Гаврилов О.В. Особливі діти в закладі і соціальному середовищі : навчальний посібник. Кам'янець-Подільський : Аксіома, 2009. 308 с.

${ }^{6}$ Teaching Developmentally Disabled Children: The Me Book by O. Ivar Lovaas. Department of Psyhology University of California, Los Angeles, 1981. 205 p. 
Д. Матіяш, Л. Ніцой, О. Осмоловської, Є. Пірог, О. Радушинської, О. Сайко та інших ${ }^{7}$.

Отже, варто особливу увагу приділити питанню індивідуальних особливостей дітей з інтелектуальними порушеннями, беручи за основу узагальнені медичні, соціальні й психологічні показники розвитку, представлені науковим доробком олігофренопедагогіки, але не втрачаючи фокусу індивідуального підходу до навчання й виховання особистості.

\section{3. Особливості розвитку дітей 3 інтелектуальними} порушеннями та їх вплив на організацію діяльності педагогічних працівників

Для активного впровадження інклюзивної моделі в освіті нам необхідно зрозуміти особливості розвитку дітей відповідної категорії, оскільки для якісного обгрунтування необхідності використання тієї чи іншої технології необхідне розуміння як індивідуальних особливостей дитини, так й узагальненого досвіду педагогічної роботи з відповідною групою дітей.

Так, для дітей із легким ступенем розумової відсталості (легка розумова субнормальність, легка олігофренія, дебільність) властиві:

- повільне оволодіння мовою, що дає змогу використовувати мову для щоденного спілкування, підтримувати розмови на побутову тематику;

- фонетичні викривлення, обмеження словникового запасу, недостатність розуміння слів, їх неточне розуміння та неадекватне вживання;

- труднощі під час формулювання своїх думок;

- труднощі орієнтування в навколишньому середовищі (нерозуміння подібності й відмінності між предметами та явищами; не відчувають відтінки, помилково оцінюють глибину, об'єм різних властивостей предметів, віддаленість від спостерігача) $)^{8}$.

Окремо варто відзначити, що в дітей цієї категорії:

- довільна увага нецілеспрямована, необхідне значне напруження під час іiі концентрування, фіксації, вона нестійка, швидко виснажується;

- мислення конкретне, обмежене безпосереднім досвідом i необхідністю забезпечення нагальних потреб, непослідовне й стереотипне, некритичне;

7 INCLUSIVE Books. URL: https://inclusivebooks.org/index.php/books (дата звернення: 25.04.2020).

${ }^{8}$ Гаврилов О.В. Особливі діти в закладі і соціальному середовищі : навчальний посібник. Кам'янець-Подільський : Аксіома, 2009. 308 с. 
- пам'ять характеризується уповільненістю, нестійкістю, неточністю під час відтворення певних подій, найбільш нерозвиненим $\epsilon$ логічне опосередковане запам'ятовування;

- емоції характеризуються нестійкістю, недостатньо диференційовані; часто бувають неадекватними, непропорційні впливам зовнішнього світу за своєю динамікою;

- психомоторний недорозвиток проявляється в уповільненні темпу розвитку локомоторних функцій, у непродуктивності й недостатній доцільності рухів, у руховій тривожності, неадекватній руховій активності ${ }^{9}$.

За належної підтримки з боку педагогічних працівників дитина 3 легким ступенем розумової відсталості зможе досягти досить суттєвих успіхів у навчанні та набути повної самостійності.

Для дітей із помірним ступенем розумової відсталості (помірна розумова субнормальність, помірна олігофренія, імбецильність) притаманні:

- відставання в розвитку розуміння та використання мовлення (краще розуміють звернене мовлення; не можуть самостійно побудувати складну мовленнєву конструкцію; здатні повторити мовленнєві висловлювання інших);

- розвиток навичок самообслуговування та функцій рухового апарату відстає;

- спостерігаються значні порушення уваги: швидко розсіюється, діти повільно концентруються, часто відволікаються на другорядні ознаки, не вміють довго ії утримувати на одній діяльності;

- пам'ять формується досить повільно, матеріал запам'ятовується лише після багаторазових повторень, швидко забувається;

- недоліки мислення проявляються в цієї категорії дітей під час формування в них навичок читання, письма, рахунку (не вміють своєчасно користуватися вже засвоєними діями, не обдумують свої вчинки, не передбачають результат; повільно утворюють логічні зв'язки та, як правило, краще запам'ятовують те, що безпосередньо пов'язується із задоволенням їхніх фізіологічних потреб) ${ }^{10}$.

Отже, дитина 3 помірною розумовою відсталістю за відповідної підтримки та вправлянні в отриманні знань і навичок зможе досягти часткової самостійності, а також показати досить якісне володіння певною інформацією, що є необхідною для життя.

${ }^{9}$ Гаврилов О.В. Особливі діти в закладі і соціальному середовищі : навчальний посібник. Кам'янець-Подільський : Аксіома, 2009. 308 с.

${ }^{10}$ Там само. 
Для осіб із тяжким ступенем розумової відсталості (тяжка розумова субнормальність, тяжка олігофренія, тяжка імбецильність) притаманні низький рівень розвитку моторики, порушення координації рухів, наявність інших відхилень, які зумовлені органічними порушеннями головного мозку. Оскільки формування навіть елементарних знань з рахунку, письма, читання не дає навіть найменших просувань у цьому напрямі, робота 3 ними зводиться до розвитку й простого тренування необхідних навичок самообслуговування та санітарно-гігієнічних навичок, навичок соціальної адаптації й виконання елементарних трудових операцій. Педагоги повинні враховувати й те, що самостійно використати навіть натреновані знання діти цієї категорії в більшості випадків не зможуть. Під час формування навичок соціалізації необхідно мати на увазі, що в дітей цієї групи не має достатнього для спілкування словникового запасу.

Спостерігається значне порушення вищих психічних функцій. Вони запам'ятовують лише ту діяльність або ті явища чи процеси, які викликають у них позитивні емоційні переживання. Сконцентрувати увагу надзвичайно складно ${ }^{11}$.

На жаль, основна відмінність дітей, які мають тяжку розумову відсталість, від тих, хто має помірну розумову відсталість, полягає в тому, що порушення впливає на моторні функції організму й дитина втрачає здатність до самообслуговування. Це основна причина іiі низької соціалізації та можливості входження в самостійне життя.

Глибокий ступінь розумової відсталості (глибока розумова субнормальність, глибока олігофренія, ідіотія) у дітей характеризується повною відсутністю пізнавальної діяльності; порушеннями смакових і нюхових відчуттів; відсутністю емоційних реакцій; апатичністю, повільністю в одних випадках i злобливістю, агресивністю, дратівливістю в інших.

Іще одна група дітей, що включені до цього переліку, - діти із затримкою психічного розвитку (далі - ЗПР). ІІхня особливість проявляється у відсутності мотивації до навчання, низькій пізнавальній активності й бажанні пошуку «легких чи обхідних шляхів». У разі затримки психічного розвитку:

- усі функції вищої нервової діяльності (пам'ять, мова, мислення, емоції, увага та уява) відстають;

- слабкий стан нервової системи призводить до швидкої втомлюваності, низької працездатності;

${ }^{11}$ Гаврилов О.В. Особливі діти в закладі і соціальному середовищі : навчальний посібник. Кам'янець-Подільський : Аксіома, 2009. 308 с. 
- сприйняття інформації обмежене як в часі, так і в обсягах, що не залежить від використовуваного аналізатора;

- провідною діяльністю так і залишається гра тощо ${ }^{12}$.

Важливим складником успішного подолання ЗПР $\epsilon$ комфортне входження дитини в нове оточення, що сприятиме ії успішності в новій для неї діяльності та поступовій зміні на цьому фоні провідної діяльності з гри на навчання. Розуміння потреб дитини, використання спеціальних корекційних вправ, завдань і дидактичних ігор, додаткове розвантаження під час перерв і хвилинок відпочинку дадуть дитині змогу «пережити» стресовий період із найменшими труднощами, а підтримка з боку вихователя чи вчителя дасть можливість відчути власну успішність.

Сьогодні до цієї групи також належать педагогічно занедбані діти, які за основними характеристиками схожі на дітей із ЗПР, але мають свої внутрішні відмінності. Часто науковці поєднують поняття «педагогічно занедбані» 3 «важковиховуваними», відзначаючи, що це діти, які систематично порушують установлені норми й правила поведінки, 3 відразою ставляться до навчання, виявляють негативізм до соціального оточення ${ }^{13}$. Таким дітям притаманні неправильно сформовані потреби (матеріальні потреби переважають над моральними), для їх задоволення використовують засоби, які не завжди відповідають нормам моралі; перебувають поза учнівським колективом; у них недостатньо розвинута потреба в пізнанні навколишнього світу; не розвинута, засмічена вульгаризмами, жаргонною лексикою мова; спостерігається непослідовність, суперечливість у поглядах і переконаннях, а також відсутні чіткі уявлення про норми поведінки; обмеженість інтелектуальних інтересів; переважно приховують свою діяльність від батьків, учителів та однокласників.

Кожна категорія, описана вище, потребує «особливої» уваги з боку вихователя чи вчителя, оскільки саме ці діти потребують додаткового часу та пошуку індивідуального підходу, заснованого на довірі й в окремих випадках конфіденційності інформації. Робота 3 останніми двома категоріями ускладнюється ще й тим, що в багатьох випадках ці діти не мають відповідних документів для оформлення їх на інклюзивну форму навчання. Тому вихователь чи вчитель не матимуть змоги долучити асистента до роботи з ними.

12 Родителям, воспитывающим детей с задержкой психического развития : методические рекомендации / сост. Т.А. Титеева. Южно-Сахалинск : Изд-во ИРОСО, 2017. $28 \mathrm{c}$.

${ }^{13}$ Поняття «педагогічно занедбані діти». База даних «Віртуальний методичний кабінет Надбузького професійного аграрного лічею». URL: https://npal.jimdo.com/ головна/виховна-робота (дата звернення: 29.04.2020). 
Саме тому необхідно «озброїти» педагогів інклюзивних груп i класів досить дієвими технологіями побудови комунікації з дітьми 3 інтелектуальними порушеннями. Однією з таких технологій може стати арт-терапія, елементи якої вчитель, вихователь та асистент зможуть використовувати під час занять та уроків.

\section{2. Особливості використання арт-терапевтичних технологій}

у роботі з дітьми з інтелектуальними порушеннями

У сучасних умовах арт-терапія набуває особливої популярності не лише через простоту застосування. Це технологія, що виконує низку функцій, які є актуальними для роботи з дітьми з інвалідністю:

- створює атмосферу успіху та довіри;

- підвищує впевненість у своїх можливостях і покращує розуміння своїх переживань;

- художній образ сприяє інтеграції та усвідомленню різних почуттів;

- художня продукція, що дає змогу здійснити динамічний аналіз досвіду й досягнень особистості;

- дає можливість катарсису та задоволення різноманітних психологічних потреб особистості ${ }^{14}$.

Усе це також є досить важливим для організації роботи 3 дітьми 3 інтелектуальними порушеннями, оскільки проблема вибору методів для здійснення психокорекції поведінкових розладів має більш глибокий рівень і спирається на те, що для більшості психокорекційних методик у дитини має бути сформовано інтелектуальні здібності. Але для дітей 3 інтелектуальними порушеннями досягти достатнього для опанування таких методик рівня є непосильним завданням ${ }^{15}$. Саме тому наша увага звернена на використання технологій арт-терапії.

Цей напрям сьогодні розвивають як спеціалісти, так і ті, хто володіє навичками в певних галузях мистецтва, що призводить, з одного боку, до величезної різноманітності способів і форм використання мистецтва, але водночас ми бачимо засилля практичних методів без відповідного обгрунтування та апробації їх ефективності й результативності. Отже, у багатьох випадках варто говорити про арт-педагогіку чи художньотворчу діяльність, адже в цьому разі такі методи не потребують включати терапевтичний (психологічний) складник до мети та завдань використовуваної вихователем, вчителем, асистентом вправи.

14 Полторак Л.Ю. Арт-терапія в соціальній роботі : навчальний посібник. Херсон : ФОП Грінь Д.С., 2014. 152 с.

15 Березка С.Ф. Особливості психокорекції поведінкових розладів дітей 3 порушенням інтелектуального розвитку засобами арт-терапії : автореф. дис. ... канд. психол. наук : 19.00.08. Київ, 2019. 21 с. 
Практика роботи із цією категорією дітей показала, що, окрім використання вже наявних методів арт-терапевтичної роботи, необхідно приділити особливу увагу супутнім факторам. Це дало нам змогу окреслити такий алгоритм дій, що убезпечить як дитину, так і педагога від стресових ситуацій.

Перший етап «Заочне знайомство». Цей етап передбачає знайомство з висновками інклюзивно-ресурсного центру, спілкування 3 батьками, спостереження за дитиною та сімейною структурою до моменту знайомства, а також використання вже наявних програм отримання інформації та налагодження взаємодії $з$ дитиною.

Серед досліджень i розробок програм 3 роботи 3 дітьми 3 інвалідністю, які сьогодні проводяться, варто відзначити такі: застосування в системі психолого-педагогічного супроводу дітей 3 інвалідністю тренінгових форм арт-терапевтичної роботи; розвивальну модульно-тренінгову арт-терапевтину програму «Подорож країною цінностей»; розвивальну трикомпонентну модульно-тренінгову арттерапевтичну програму «Світ і я»; організацію конструктивної художньо-творчої арт-терапевтичної взаємодії дітей 3 функціональними обмеженнями та їхніх батьків; забезпечення наскрізного арт-терапевтичного супроводу дітей 3 функціональними обмеженнями тощо ${ }^{16}$.

Окремої уваги потребує програма 3 психокорекції поведінкових розладів дітей 3 порушенням інтелектуального розвитку, що розроблена для дітей дошкільного віку, але окремі елементи якої можуть бути використані й у початковій школі. Так, серед тестового матеріалу автор у роботі використовує такий діагностичний комплекс для вивчення особливостей видів поведінкових розладів дітей 3 порушеннями інтелектуального розвитку: агресивна поведінка: «Ланцюг дій» (діагностика рівня самоконтролю), «Одного разу» (діагностика виду локусу контролю), «Кактус» (аналіз особистісних якостей), експертна оцінка за методикою «Виконання правил поведінки дитиною» (визначення рівня дисциплінованості), методика Рене Жиля (діагностика особливостей взаємин 3 однолітками та батьками), експертна оцінка за результатами анкетування за методикою Г. Лаврентьєва й Т. Титаренко (визначення особливостей емоційного стану); гіперактивна поведінка: тепінг-тест (діагностика здатності до психічних навантажень), анкета визначення рівня імпульсивності в дошкільника (діагностика характеру моторної активності), кольоровий

${ }^{16}$ Хіля А.В. Виховання у дітей $з$ функціональними обмеженнями ціннісного ставлення до життя засобами арт-терапії : дис. ... канд. пед. наук : 13.00.07. Вінниця, 2017. $339 \mathrm{c}$. 
тест Люшера (оцінювання особливостей емоційного фону), «Будиночок» (діагностика рівня регуляції поведінки), експертна оцінка за результатами спостереження та методика Рене Жиля (визначення особливостей взаємодії 3 оточуючими) ${ }^{17}$.

Саме ці матеріали дадуть змогу конкретизувати й спрямувати роботу учасників мультидисциплінарної команди для отримання максимально якісних результатів соціалізації дитини 3 інтелектуальними порушеннями.

Другий етап «Комунікація», що включає знайомство дитини 3 приміщенням, налагодження контакту 3 вихователем, учителем, асистентом. У цей період педагогічний працівник може спостерігати за дитиною, яка «залишилася без нагляду батьків». Тобто це період, коли дитина перестає відчувати присутність значимих дорослих, їхню опіку та починає «пробувати» отриману свободу й самостійність. Це також період установлення рамок у спілкуванні, коли ми визначаємо ролі та вчимося нових форм взаємодії.

Важливо пам'ятати, що в такий момент асистент і вчитель чи вихователь мають продовжувати спостерігати за діями дитини, не втрачаючи контролю над ситуацією. Отже, отримана інформація дасть змогу ефективніше продовжити підбір корекційних i розвиваючих вправ, дидактичних матеріалів, ігор, а також сприятиме обговоренню та спільній дії всіх членів мультидисциплінарної команди.

Tретій етап «Акт творчості». І це не обов'язково має бути робота, пов'язана з творчою діяльністю. Сам процес взаємодії вже є творчістю. І в цьому випадку можливі декілька форм взаємодії:

- групова активність із безпосереднім включенням дитини 3 інтелектуальними порушеннями до роботи з усіма дітьми;

- групова активність із безпосереднім включенням дитини 3 інтелектуальними порушеннями до роботи 3 окремо визначеною групою дітей;

- групова активність 3 опосередкованим включенням дитини 3 інтелектуальними порушеннями до роботи (індивідуальна робота за тією ж тематикою, за якою працюють усі діти);

- індивідуальна робота дитини з інтелектуальними порушеннями за спеціально підібраною методикою.

У цьому контексті варто зауважити, що досить часто робота асистента зводиться до індивідуальної діяльності. Позитивним, на нашу думку, у цьому форматі $є$ таке:

17 Березка С.Ф. Особливості психокорекції поведінкових розладів дітей 3 порушенням інтелектуального розвитку засобами арт-терапії : автореф. дис. ... канд. психол. наук : 19.00.08. Київ, 2019. 21 с. 
- реалізується диференційний та індивідуальний підхід до дитини під час арт-терапевтичного процесу;

- $€$ можливість якісного засвоєння запропонованого матеріалу й ефективної корекційно-компенсаційної роботи;

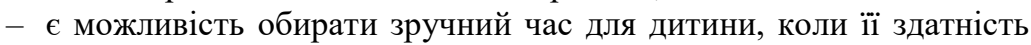
до засвоєння матеріалу, концентрація та бажання працювати $\epsilon$ найвищими ${ }^{18}$.

Проте основний мінус індивідуальної форми арт-терапевтичної роботи - обмеженість навчального-виховного й корекційнопедагогічного простору одним фахівцем, що позбавляє дитину 3 функціональними обмеженнями можливості формування досвіду соціальної самореалізації ${ }^{19}$.

Групова форма роботи в усіх варіантах дає дитині змогу бути включеною в колективну творчу справу, де, спостерігаючи та наслідуючи поведінку інших дітей, вона може отримати відчуття власної успішності й насолоди від цього.

Окрім того, кожна окремо взята художньо-творча діяльність арттерапевтичного характеру може сприяти:

- зняттю психофізичного напруження дитини та зменшенню прояву агресії чи аутоагресії;

- зняттю психоемоційного напруження і стабілізації емоційних станів.

Усе це дасть можливість вихователю, вчителю та асистенту поступово сформувати навички саморегуляції емоційних станів, довести до того максимуму, який доступний дитині.

Четвертий етап «Рефрлексія». Цей етап важливий як для дитини, так i для педагогічних працівників, оскільки дитина може продемонструвати власне ставлення до тих процесів, що відбуваються в закладі освіти, через ставлення до власної творчості, тим самим надаючи досить потужний матеріал педагогу для аналізу та рефлексії організованої взаємодії, пошуку наступних шляхів взаємодії.

У свою чергу, для педагогів цей етап важливий тим, що на основі відпрацьованого матеріалу, реакцій дитини, ii успіхів у виконанні завдань і взаємодії з оточуючими можна спроектувати наступні кроки взаємодії та вправи для опанування основного матеріалу, передбачити можливі емоційні чи моторні реакції в подальшій роботі. Також це важливий елемент для взаємодії мультидисциплінарної команди, яка,

${ }^{18}$ Вознесенська О., Сидоркіна М. Арт-терапія у подоланні психічної травми : практичний посібник. Київ : Золоті ворота, 2015. 198 с.

19 Хіля А.В. Арт-терапія в системі засобів виховання ціннісного ставлення до життя в дітей та молоді з функціональними обмеженнями : методичні матеріали. Вінниця, 2017. Ч. 1. 252 с. 
отримуючи відповідну інформацію від реалізації попереднього етапу роботи 3 дитиною, може скласти план взаємодії відповідно до потреб дитини, беручи за основу прогнозовані кроки педагогів щодо соціалізації й навчання дитини.

\section{ВИСНОВКИ}

Результати проведеного дослідження дають змогу зробити висновок, що для побудови ефективної взаємодії 3 дитиною 3 порушенням інтелекту незалежно від специфіки чи рівня закладу освіти педагогічний колектив має бути обізнаний з особливостями соціалізації такої дитини відповідно до рівня іiі інтелектуальних здібностей, а також супутніх розладів і проявів вищих психічних функцій, поведінкових реакцій. Особливого значення відповідні знання набувають для педагогів, які працюють в умовах інклюзивного освітнього простору, адже від цього залежать не лише організаційно-педагогічні умови, які мають бути створенні у відповідній групі чи класі, а й визначені індивідуальні умови забезпечення освіти й виховання дітей 3 інтелектуальними порушеннями.

Отже, нами запропоновано основні тези щодо особливостей розвитку дітей з інтелектуальними порушеннями, щодо їх впливу на організацію діяльності педагогічних працівників, а також поетапно розписано роботу відповідних педагогічних працівників із залученням мультидисциплінарної команди. Окрему увагу в реалізації відповідних етапів роботи щодо соціалізації дитини цієї категорії нами приділено особливостям використання арт-терапевтичних технологій. Зокрема, описано наявні програми 3 використанням арт-терапії для роботи 3 дітьми 3 інвалідністю, розглянуто тестові методики вивчення особливостей дитини 3 інтелектуальними порушеннями, а також описано особливості впливу на психофізичний і психоемоційний стан дітей відповідних технологій і їхню дієвість у освітньому й виховному процесах.

Саме тому, на нашу думку, цей напрям потребує подальшого дослідження та формування спеціалізованої й по можливості досить уніфікованої програми соціальної адаптації дітей з інтелектуальними порушеннями засобами арт-терапії, яка водночас може бути адаптована та модифікована відповідно до потреб дитини й педагогічних працівників.

\section{АНОТАЦІЯ}

Питання «включення» дітей 3 інвалідністю в освітній процес закладів дошкільної освіти, загальноосвітніх навчальних закладів порушується досить гостро на всіх рівнях державного управління 
освітнім процесом. Але разом із тим певним «викликом» до освітянської громади, що не має профільної корекційної чи дефектологічної освіти, є питання навчання та виховання дітей 3 інтелектуальними порушеннями. Варто закцентувати на тому, що основним завданням інклюзивної освіти $є$ не навчання, а соціалізація дитини, сприяння іiі адаптації та входженню в соціум як повноцінного члена громади, забезпечуючи в майбутньому прагнення до самореалізації. Саме тому, акцентуючи увагу вихователів, учителів та асистентів на питаннях соціалізації, ми звертаємо їхню увагу на різноманітні форми використання мистецтва.

Мистецтво є невидимою рушійною силою для пошуку «спільної мови», адже в процесі творчості не потрібні слова: кожен може висловитися через власний творчий доробок. Окрім того, саме творча робота може зменшити вплив соціального тиску, надати емоційної стабільності особистості, допомогти відреагувати на позитивні чи негативні події, розкрити таланти, «зняти» тягар особистих переживань і проблем, як зовнішнього впливу, так і внутрішніх. I одним із таких потужних елементів, що може бути використаний в освітньому процесі, $\epsilon$ арт-терапія.

\section{ЛІТЕРАТУРА}

1. Гаврилов О.В. Особливі діти в закладі і соціальному середовищі : навчальний посібник. Кам'янець-Подільський : Аксіома, 2009. 308 с.

2. Березка С.Ф. Особливості психокорекції поведінкових розладів дітей 3 порушенням інтелектуального розвитку засобами арт-терапії : автореф. дис. ... канд. психол. наук : 19.00.08. Київ, 2019. 21 с.

3. Teaching Developmentally Disabled Children: The Me Book by O. Ivar Lovaas. Department of Psyhology University of California, Los Angeles, $1981.205 \mathrm{p}$.

4. INCLUSIVE Books. URL: https://inclusivebooks.org/index.php/books. (дата звернення: 25.04.2020).

5. Родителям, воспитывающим детей с задержкой психического развития : методические рекомендации / сост. Т.А. Титеева. ЮжноСахалинск : Изд-во ИРОСО, 2017. 28 с.

6. Поняття «педагогічно занедбані діти». База даних «Віртуальний методичний кабінет Надбузького професійного аграрного ліџею». URL: https://npal.jimdo.com/головна/виховна-робота (дата звернення: 29.04.2020).

7. Полторак Л.Ю. Арт-терапія в соціальній роботі : навчальний посібник. Херсон : ФОП Грінь Д.С., 2014. 152 с.

8. Хіля А.В. Виховання у дітей з функціональними обмеженнями ціннісного ставлення до життя засобами арт-терапії : дис. ... канд. пед. наук : 13.00.07. Вінниця, 2017. 339 с. 
9. Вознесенська О., Сидоркіна М. Арт-терапія у подоланні психічної травми : практичний посібник. Київ : Золоті ворота, 2015. $198 \mathrm{c}$.

10. Хіля А.В. Арт-терапія в системі засобів виховання ціннісного ставлення до життя в дітей та молоді з функціональними обмеженнями : методичні матеріали. Вінниця, 2017. Ч. 1. 252 с.

\section{Information about the authors:} Khilya A. V.,

Candidate of Pedagogical Sciences, Head of the Inclusive Education Section Vinnytsia Mykhailo Kotsiubynskyi State Pedagogical University 32, Ostrozkogo str., Vinnytsia, Ukraine ORCID ID: 0000-0002-1287-2901

Sarancha I. G., Candidate of Pedagogical Sciences, Lecturer at the Department of Psychology and Social Work Vinnytsia Mykhailo Kotsiubynskyi State Pedagogical University

32, Ostrozkogo str., Vinnytsia, Ukraine ORCID ID: 0000-0002-5715-6271 